\title{
Comparative Study for Organic and Inorganic Draw Solutions in Forward Osmosis
}

\author{
Ahmed Faiq Al-Alalawy* Talib Rashid Abbas** \\ Hadeer Kadhim Mohammed*** \\ *,*** Department of Chemical Engineering /College of Engineering/ University of Baghdad \\ **Water and Environment Directorate/ Ministry of Science and Technology \\ *Email: Ahmedalalawy@yahoo.com \\ **Email: Talibrshd@yahoo.com

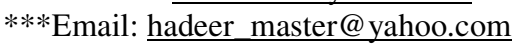

Received 20 March 2015; accepted 24 August 2016)

https://doi.org/10.22153/kej.2017.08.007

\begin{abstract}
The present work aims to study forward osmosis process using different kinds of draw solutions and membranes. Three types of draw solutions (sodium chloride, sodium formate, and sodium acetate) were used in forward osmosis process to evaluate their effectiveness with respect to water flux and reverse salt flux. Experiments conducted in a laboratory-scale forward osmosis (FO) unit in cross flow flat sheet membrane cell. Three types of membranes (Thin film composite (TFC), Cellulose acetate (CA), and Cellulose triacetate (CTA)) were used to determine the water flux under osmotic pressure as a driving force. The effect of temperature, draw solution concentration, feed and draw solution flow rate, and membrane types, were studied with respect to water flux. The results showed an increase in water flux with increasing feed temperature and draw solution concentrations In addition, the flux increased with increasing feed flow rate while the flux was inversely proportional with the draw solution flow rate. The results showed that reverse osmosis membranes (TFC and CA) are not suitable for using in FO process due to the relatively obtained low water flux when compared with the flux obtained by forward osmosis membrane (CTA). $\mathrm{NaCl}$ draw solution gave higher water flux than other draw solutions and at the same time, revealed higher reverse salt flux.
\end{abstract}

Keywords: Forward osmosis, internal concentration polarization, Reverse salt flux, Water flux.

\section{Introduction}

Fresh water scarcity is a basic problem in many places in the world. One of the most challenges of this century is the increasing for the demand of fresh water for drinking and other utilities such as food production and other industrial needs. Presently over one-third of the world's population suffers of shortage of clean water [1]. Therefore one of the most critical challenges of the $21^{\text {st }}$ century is to face the enlarging demand for clean water. Forward osmosis (FO) has been considered as an emerging technology for water reuse and desalination [2, 3].
FO, unlike pressure- driven membrane process is a naturally process of osmosis-driven which is including semipermeable membrane and a draw solution. The semipermeable membrane, ideally, work as a barrier which rejects salts or undesired substances but allows for water to pass through. The mechanism of forward osmosis process "physical phenomenon" is water moves through selectively permeable membrane from the low solute concentration feed solution (FS) to the concentrated draw solution (DS) as a result of osmotic gradient and retaining the solute on both sides of the membrane. The driving force in FO process is generated naturally due to difference in osmotic pressure between feed and draw 
solutions, hence this phenomenon offers many advantages like lower energy cost and less membrane fouling potentials [4]. The main benefits of using FO are that the process operates with low or no hydraulic pressure, it have high retaining of wide range of undesired substances and it have lower membrane fouling potentials [4,5]. The flow resistance in the membrane module represents the only kind of pressure in FO process, therefore, the equipments used is very simple and the support of membrane is less of a problem. FO process has also the advantages of concentrating the feed without the need of high pressure or temperature which they may be detrimental to the feed solution $[6,7]$.

In this research we describe the forward osmosis process by using three types of membranes (TFC, CA and CTA) and three types of draw solutions, one of them is inorganic $(\mathrm{NaCl})$ and the two others are organic (sodium acetate and sodium formate). Several researchers used different types of draw solutions for the application of FO process. In previous studies $[8,9,10,11,26]$ the most commonly draw solution used is the inorganic ionic salts such as sodium chloride $(\mathrm{NaCl})$ due to the low molecular weight and high solubility. The type of draw solution plays a basic role in FO process, therefore the selection of an ideal draw solution is an important not only in promoting the efficiency of the FO process, but also save cost for the subsequent steps in re-concentration and replenishing the draw solute. An effective draw solution have to possess a very specific characteristics, It should have a high osmotic efficiency which means it has to be highly soluble in water and low molecular weight so as to generate a high osmotic pressure and as a result high water flux and feed water recovery. Chemical compatibility of the membrane is another factor for ideality of the draw solution which may degrade or react with the membrane. Finally, the processes which involve production of potable water without even traces of solute, the draw solute have to be easily, efficiently and economically be separated and recycled. The attention on draw solutions, as a commercially available, has begun from the late of 1990s, many inorganic salts where used in the FO process. Generally, draw solutions from inorganic salts impart high fluxes and can be recovered easily by distillation or reverse osmosis $[15,16]$. In previous studies $[10,11,17,18]$ the most commonly draw solution used in FO processes were who have lower molecular weight and higher solubility. Several inorganic salts were prepared and considered as draw solution in FO processes and the selected salts were then assessed by determining their water fluxes and reverse salt fluxes [18].

Organic ionic salt solutions are recently proposed as draw agents in forward osmosis processes. The organic salt is defined as any organic acid (anion) who combined with any inorganic or organic base (cation). The main advantage of using organic salts as draw agent is to reduce the negative influence of the accumulation of draw solute in the feed side due to reverse salt flux and this phenomenon is desirable especially in osmotic membrane bioreactor (OMBR) systems for waste water treatment where the organic salt is biologically degraded in the reactor. Therefore, the accumulation of organic salts is not an issue when compared with inorganic draw solution [13,27]. Generally, the organic salt who have shorter carbon chain overcome the larger carbon chain when they are similar in cation species with the same osmotic pressure. This phenomenon may be attributed to that the former has less ICP than the latter according to the higher diffusion coefficient. Another advantage for organic salts over their inorganic showed higher salt rejection in the reverse osmosis reconcentration process [14].

To make the technology of FO process advanced, many researchers studied and explored the viability of using other draw solutes [ $\left.{ }^{1}\right]$. Hydrophilic magnetic nanoparticles (MNPs) were considered one of the great potentials as draw agent [29]. The main advantage of using MNPs as draw solute is due to their interest In biomedical applications such as biocatalysis and drug delivery [30]. Another type of draw agents were recently studied and developed [31], the polymer hydrogel particles for FO desalination. The hydrogels include three-dimensional network of polymer chains which are linked by either physical or chemical bonds and have the ability to catch large volumes of water via highly concentrated of hydrophilic groups.

\section{Experimental Work 2.1. Membrane Material 2.1.1 Membrane Structure}

Three types of flat sheet membranes were used in this study. The first type was thin film composite (TFC) membrane which composed of three layers: a polyamide ultrathin top layer $(<0.5 \mu \mathrm{m})$, inter micro-porous support layer of polysulfone $40-50 \mu \mathrm{m}$, and a polyster fabric 
support $>120 \mu \mathrm{m}$. The second type of membrane was a symmetric cellulose acetate (CA) provided by GE osmonics, RO. This membrane has thick fabric backing layer which provide mechanical support. The membrane is derived from the Cseries family, a triacetate /diacetate blend has a higher flux and better mechanical stability than standard cellulose acetate. The third type was asymmetric cellulose triacetate (CTA) FO membrane delivered by HTI Albany, OR. The support layer for this FO membrane is comprised of polyster fibers with capacious voids which lead to minimize ICP and hence increase permeates flux. The thickness of the membrane is less than $50 \mu \mathrm{m}$.

\subsubsection{Membrane Hydraulic Permeability}

The determination of Water permeability was experimentally detected using compressed air to press the water through the membrane vertically (HP4750 Stirred Cell, $300 \mathrm{ml}$ processing volume, $14.6 \mathrm{~cm}^{2}$ membrane area, and 69 bar the maximum pressure). The flux of pure water through each membrane was determined under a range of pressures.

\subsection{Forward Osmosis Set-Up}

The flat sheet bench scale set-up used in this study as shown in figure 1 was to evaluate forward osmosis performance. The membrane was installed in the membrane holder in FO cell with an effective area of $140 \mathrm{~cm}^{2}$. The cell had a symmetric channels on both sides of the membrane with a dimensions of $140 \mathrm{~mm}$ high by $100 \mathrm{~mm}$ long by $5 \mathrm{~mm}$ wide and this configuration allowed for both the feed and draw solution to flow in tangential to the membrane with cocurrent flow to reduce strain on the suspended membrane. The membrane oriented with FO mode where the active layer faces the feed side and the support layer facing the draw solution side. Mesh spacer positioned at the feed side to support the membrane and enhance turbulence.

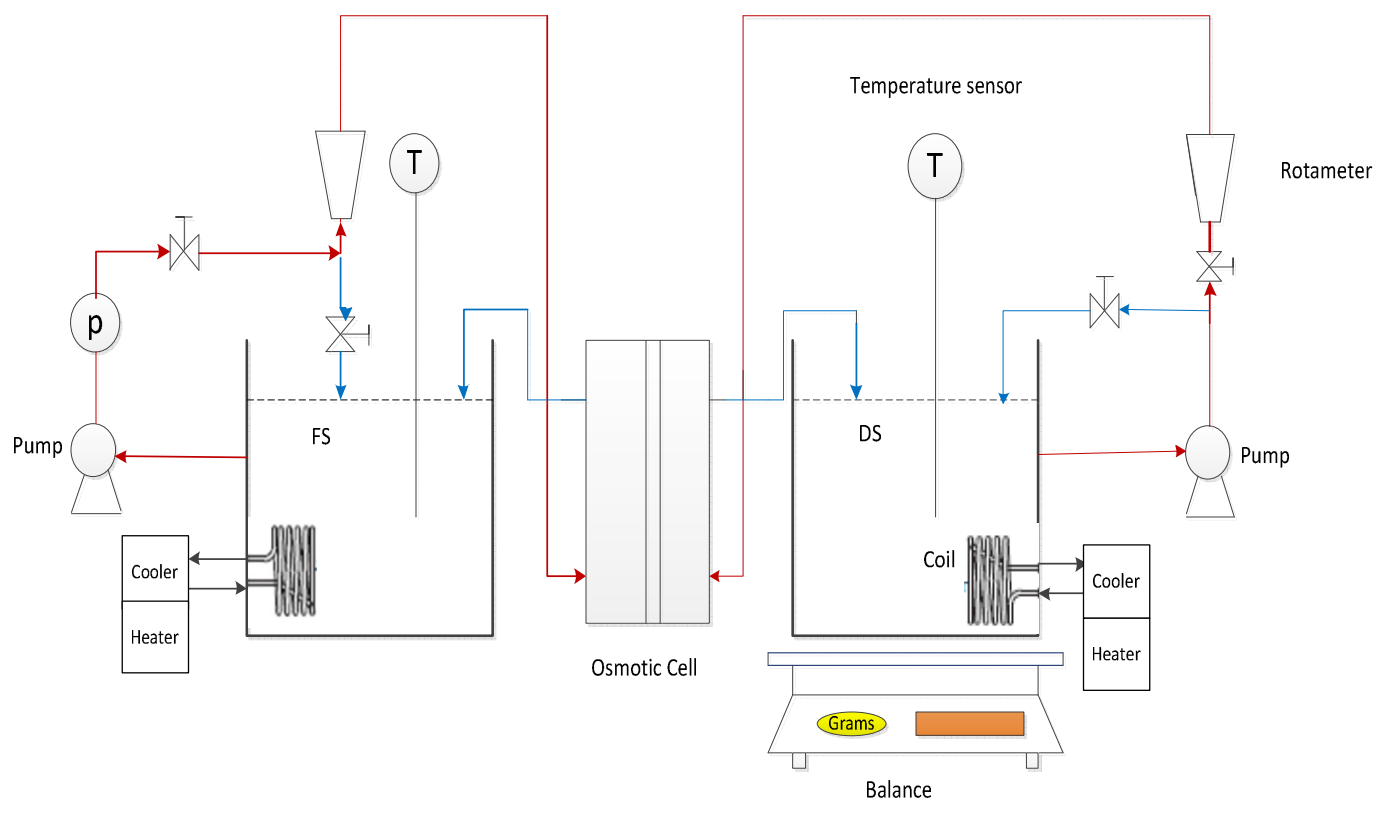

Fig. 1. Schematic diagram of the laboratory-scale forward osmosis setup.

Two centrifugal pumps were used to recirculate the feed and draw solutions on the opposite sides of the membrane with a flow rate of 1-5 1/min. The draw solution container $2 \mathrm{~L}$ capacity was placed on a digital balance with an accuracy of $(0.1 \mathrm{~g})$ to determine the weight changes of the draw solution with time in order to calculate the permeate flux. The operating temperature for both feed and draw solutions was varied between $15-40^{\circ} \mathrm{C}$ and the duration for each experiment was $4 \mathrm{~h}$ in batch mode. The temperature for both feed and draw solutions was measured and controlled by microcomputer temperature controller (accuracy $\pm 1{ }^{\circ} \mathrm{C}$ ) using cooler and heater connected to coils immersed in both solutions to keep the desired temperature. A 
conductivity meter (Ec-Meter, Basic 30, CRISON Spain, accuracy $\pm 5 \%$ ) used to measure the concentration of salts in draw solution and feed periodically and hence determine the reverse salt flux with time.

\subsection{Feed and Draw Solutions}

Distilled water was used as feed in all the experiments (conductivity, $12 \mu \mathrm{s} / \mathrm{cm}$ ) while three kinds of draw solutions were used, sodium chloride, sodium acetate, and sodium formate dissolved in distilled water. The chosen draw solutes, as specified in table 1, possess the same cation (Na) so as to be obvious and easier in comparison with respect to water and salt fluxes. The concentration of the draw solutions for all the three types was varied between $0.3 \mathrm{M}$ to $2 \mathrm{M}$.

Table 1,

Chemical Specifications of Draw Solutions.

\begin{tabular}{|c|c|c|}
\hline \multirow{5}{*}{$\begin{array}{l}\text { Sodium chloride } \\
\text { NaCl } \\
\mathrm{MW}=58.44 \mathrm{~g} / \mathrm{mol} \\
\text { Solubility = } 355 \mathrm{~g} / 1 \\
(\mathrm{H} 2 \mathrm{O})\end{array}$} & \multicolumn{2}{|c|}{ Assay $99.5 \%$ (min) } \\
\hline & \multicolumn{2}{|c|}{ Maximum limits of } \\
\hline & Ammonia & 0.002 \\
\hline & Iron & 0.002 \\
\hline & Lead & 0.0005 \\
\hline & Potassium & 0.02 \\
\hline & \multicolumn{2}{|c|}{ Sulphate 0.02} \\
\hline Sodium Formate & \multicolumn{2}{|c|}{ Assay $98 \%(\min )$} \\
\hline HCOONa & \multicolumn{2}{|c|}{ Maximum limits of } \\
\hline $\mathrm{MW}=68.03 \mathrm{~g} / \mathrm{mol}$ & \multicolumn{2}{|c|}{ Impurities (\%): } \\
\hline Solubility = $972 \mathrm{~g} / \mathrm{l}$ & Chloride & 0.01 \\
\hline$(\mathrm{H} 2 \mathrm{O})$ & Sulphate & 0.05 \\
\hline \multicolumn{3}{|l|}{$\mathrm{PH}=7.0-8.5$} \\
\hline Sodium Acetate & \multicolumn{2}{|c|}{ Assay $99 \%$ (min) } \\
\hline CH3COONa & \multicolumn{2}{|c|}{ Maximum limits of } \\
\hline $\mathrm{MW}=82.03 \mathrm{~g} / \mathrm{mol}$ & \multicolumn{2}{|c|}{ Impurities (\%): } \\
\hline $\mathrm{PH}=7.5-9.2$ & Chloride & 0.001 \\
\hline Solubility= $1233 \mathrm{~g} / \mathrm{l}$ & Phosphate & 0.0005 \\
\hline \multirow[t]{4}{*}{$(\mathrm{H} 2 \mathrm{O})$} & Sulphate & 0.0003 \\
\hline & Calcium & 0.001 \\
\hline & Iron & 0.0005 \\
\hline & Potassium & 0.02 \\
\hline
\end{tabular}

\section{Results and Discussions 3.1. Membrane Permeability}

The results of the permeability were determined from the curve slope tests for TFC, CA, and CTA membranes which were 6.6, 4.7, and $0.73 \mathrm{l} / \mathrm{m}^{2} \mathrm{~h}$. bar, respectively, as shown in
Figure 2. The results showed that the permeability of the TFC and CA membranes is much greater than CTA membrane. These results prove that TFC and CA (reverse osmosis) membranes give high fluxes under hydraulic pressure and CTA (forward osmosis) membrane give satisfactory fluxes under osmotic pressure.
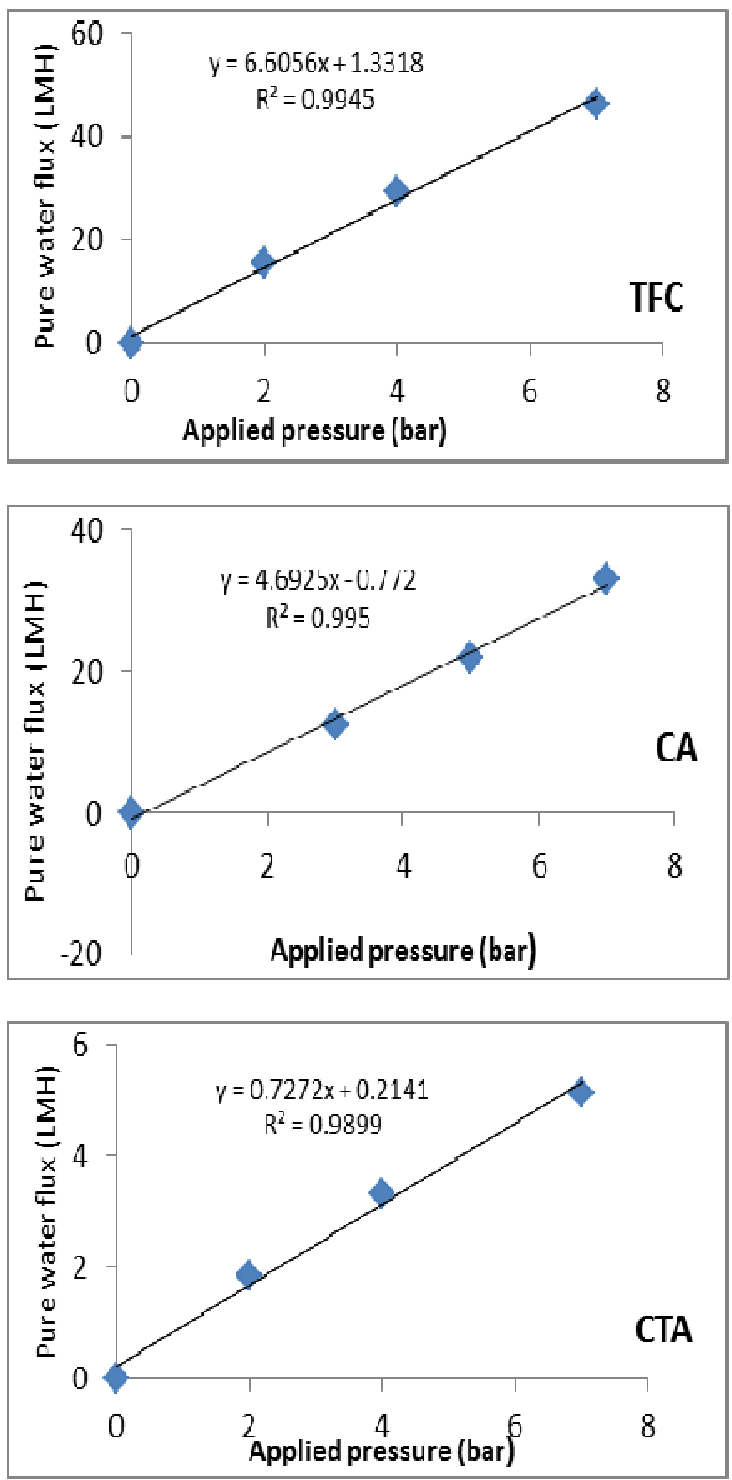

Fig. 2. Pure water flux against applied pressure for determine permeability coefficient (A): TFC membrane, CA membrane, and CTA membrane.

\subsection{Effect of Temperature}

The effect of temperature on water flux is shown in Figure 3. The experiments were carried out using three types of membranes ( TFC, CA, and CTA) with variable temperature for both feed and draw solutions $\left(15-40^{\circ} \mathrm{C}\right)$. 


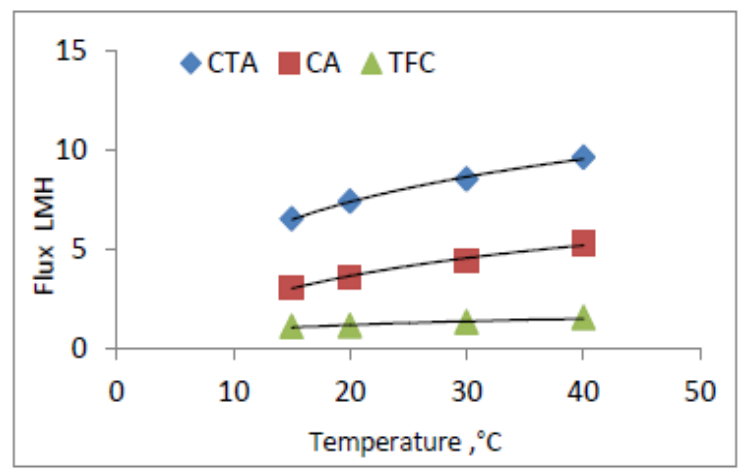

Fig. 3. Water flux in function of temperature for different membranes $(0.6 \mathrm{M} \mathrm{NaCl}, 3 \mathrm{l} / \mathrm{min}$ feed and draw Flow rate).

According to figure 3 , the water flux increase with temperature linearly and this attributed to decrease in viscosity of the feed water and this lead to increase in diffusion rate for water through the membrane outcoming in a higher permeability which is compatible with previous studies [19]. The temperature will have clear impact on ICP which become lower at higher temperature and hence higher water flux. We notice that the effect of temperature on water flux is greater when using CTA membrane when compared with CA and TFC membranes. The reason for this difference in fluxes is expected to the thick fabric and porous support layers in CA and TFC membranes which contribute to the development of internal concentration polarization (ICP) and therefore reduce the effective driving force and water flux. Figure 4 illustrates the water flux for TFC, CA and CTA membranes at different kinds of draw solutions using the same experimental conditions.

\subsection{Effect of Concentration}

Figure 4 shows that An increase in water flux was found when the concentration of the draw solution increased from $0.3 \mathrm{M}$ to $1.5 \mathrm{M}$ due to an increase in the osmotic driving force over the membrane (since osmotic pressure difference is the driving force in FO operation). As illustrated in Figure 4, The plots show that the flux is almost linear and the deviation from the linearity is due to the effects of ICP, which reduces the effective driving force of the draw solution.
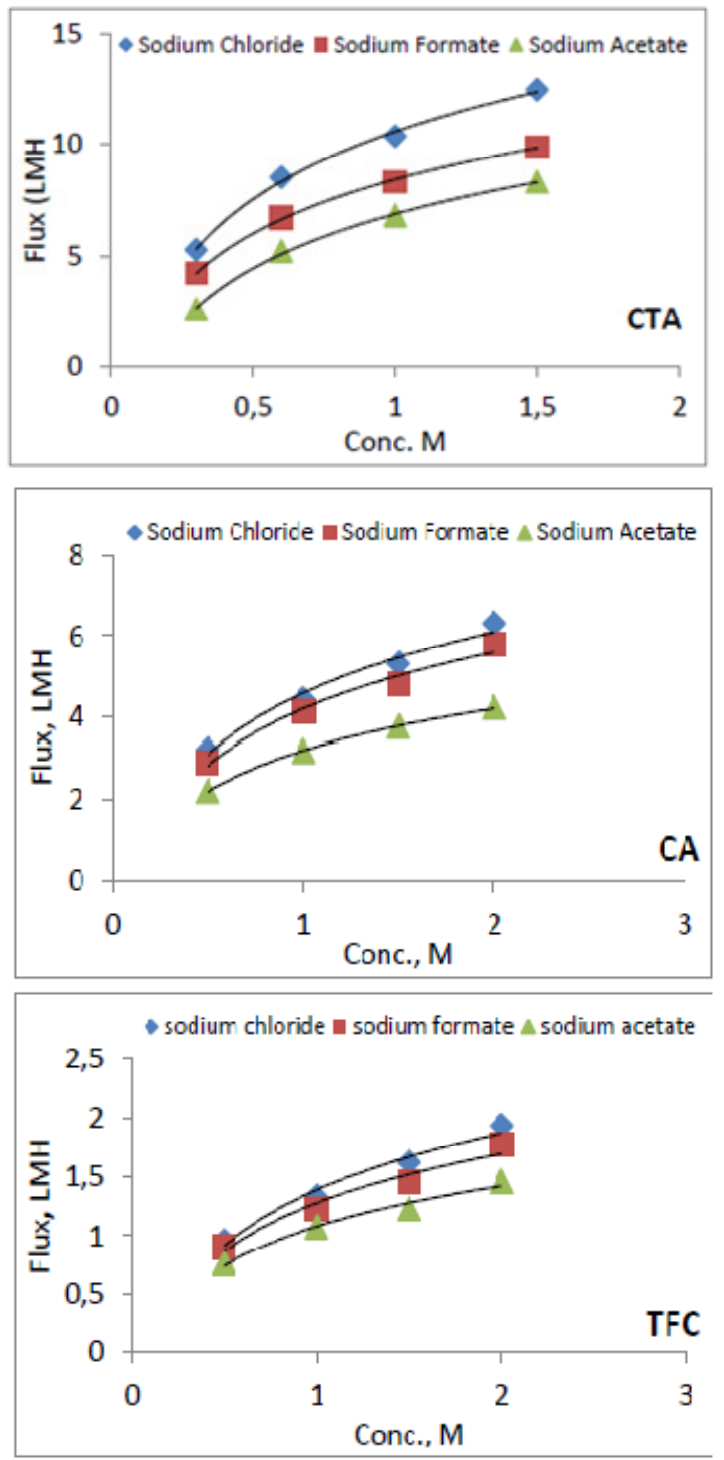

Fig. 4. Influence of draw solution concentration on water flux with different types of draw solutions and using different membranes: CTA membrane, CA membrane, and TFC membrane $\left\{30{ }^{\circ} \mathrm{C} \pm 1\right.$ temperature, $3 \mathrm{l} / \mathrm{min}$ flow rate\}.

The results indicate that water flux depend not only on concentration of draw solution but also on the kind of draw solution. We notice from plots that the water flux for sodium chloride is greater than sodium acetate and sodium formate. This could be due to a higher solute diffusion coefficient resulting in greater efficiency of $\mathrm{NaCl}$ than other draw solutes. Therefore, it can be deduced that the organic sodium salts with larger sizes have lower diffusion coefficients which are more affected by ICP than $\mathrm{NaCl}$. 


\subsection{Effect of Draw Solution}

Figure 5 represent the reverse salt flux with time for the three types of draw solutions. The figure shows higher salt flux for $\mathrm{NaCl}$ than other draw solutes and sodium acetate revealed lower salt flux. Reverse salt diffusion increase with increasing draw solution concentration due to the increasing in driving force.

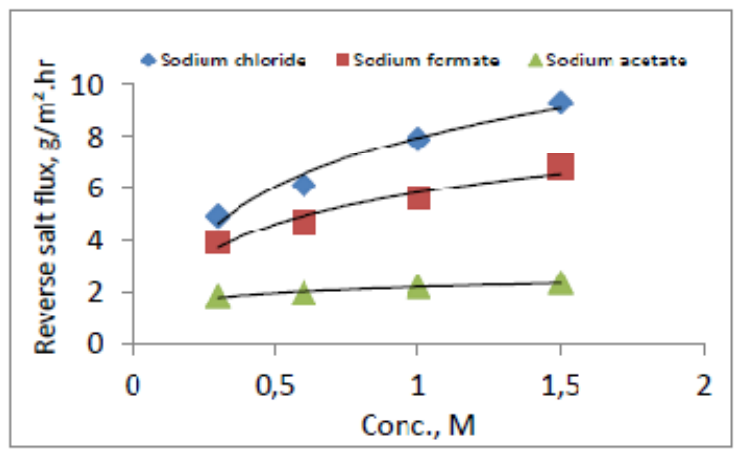

Fig. 5. Influence of draw solution concentration on reverse salt flux for different kinds of draw solutions $\left(30^{\circ} \mathrm{C}\right.$ temperature, $3 \mathrm{l} / \mathrm{min}$ flow rate, CTA membrane).

\subsection{Effect of Feed Flow Rate}

Figure 6 illustrates the effect of feed flow rate on water flux using different types of membranes.

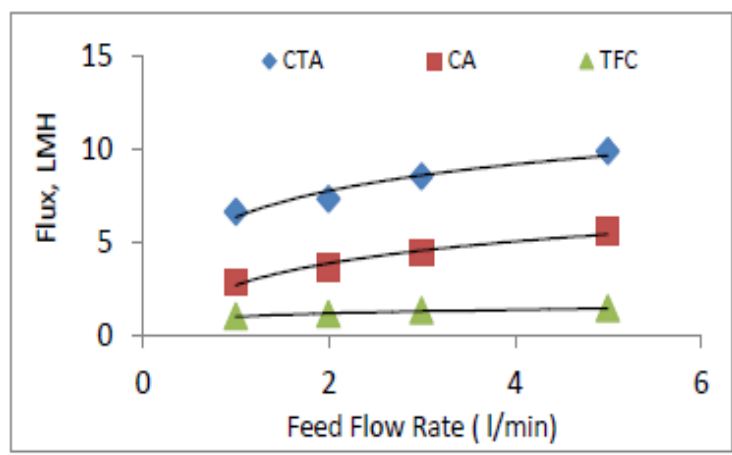

Fig. 6. Effect of feed flow rate on water flux with different membranes $\left(30^{\circ} \mathrm{C}\right.$ temperature, $0.6 \mathrm{M}$ $\mathrm{NaCl})$.

Feed velocity shows small effect on water flux and this may attributed to low concentration of salt of the feed and as a result reveal little contribution of concentrative external concentration polarization (CECP) to the flux.

\subsection{Effect of Draw Solution Flow Rate}

Figure 7 shows the influence of draw solution flow rate on water flux. The results reveal increasing of water flux with decreasing of draw solution flow rate and this may attributed to increasing the concentration build up in the vicinity of the membrane surface. This process leads to increasing the osmotic pressure in the draw solution side and hence increasing water flux.

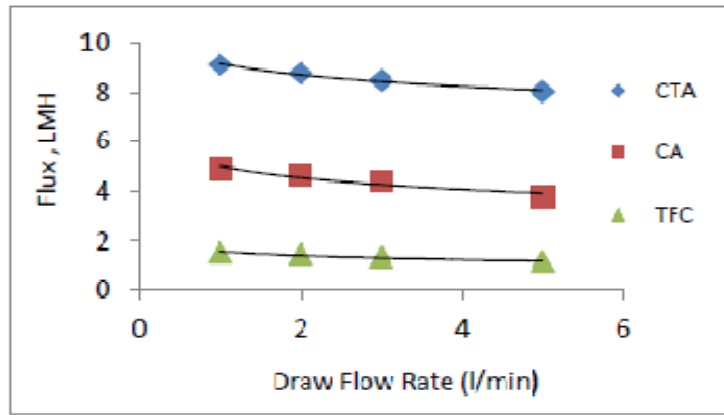

Fig. 7. Effect of draw solution flow rate on water flux at different membranes $\left(30^{\circ} \mathrm{C}\right.$ temperature, 0.6M NaCl).

The permeate water flux was assessed for the three membranes using $\mathrm{NaCl}$ as draw solution as shown in figure 8 . Every membrane was tested in a cross flow mode with $0.6 \mathrm{M}$ concentration of draw solution against distilled water as feed solution. The feed solution was coordinated against the active layer of the membrane and the draw solution was against the support layer. Both the feed and draw solutions were kept up at $30^{\circ} \mathrm{C}$ and water flux been determined with time for the Under the same test conditions. The CTA membrane had a quite higher water flux than either TFC or CA membranes.

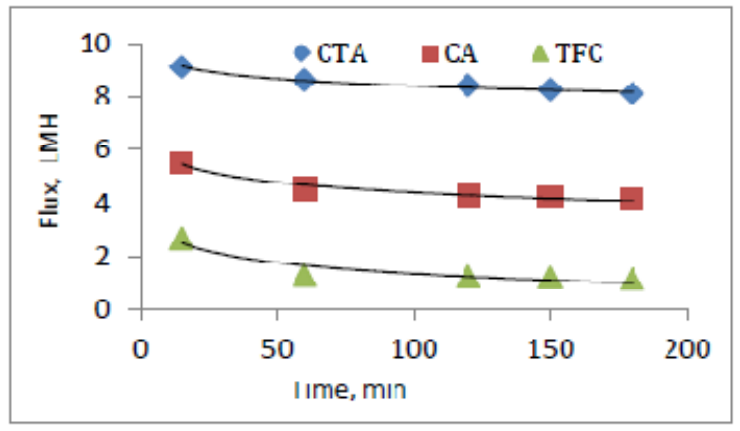

Fig. 8. Water Flux against time for different kinds of membranes $\left(30{ }^{\circ} \mathrm{C}\right.$ temperature, $3 \mathrm{l} / \mathrm{min}$ flow rate, and $\mathrm{NaCl}$ draw type). 
The difference in flux between these membranes is due to the difference in structures of the membranes, where the overall thickness of the CTA membrane is less than $50 \mu \mathrm{m}$ (consist of two layers of cellulose triacetate polymer embedded with polyster mesh as support) which is less than thickness of TFC and CA membranes $(140 \mu \mathrm{m})$ which is composed of thick fabric and porous support layers. It is concluded that these thick support layers of TFC and CA membranes may contribute to the development of internal concentration polarization and as a result reduce the effective driving force and water flux respectively. Figure 9 shows differences in salt flux values between TFC, CA, and CTA membranes and this imparity is attributed to structure of the separating layer of the membranes. The separating layer for the FO-type membrane (CTA) is less compact when compared to other RO membranes (TFC and CA) and this result reflected in lower retention ability for FO membranes than RO membranes.

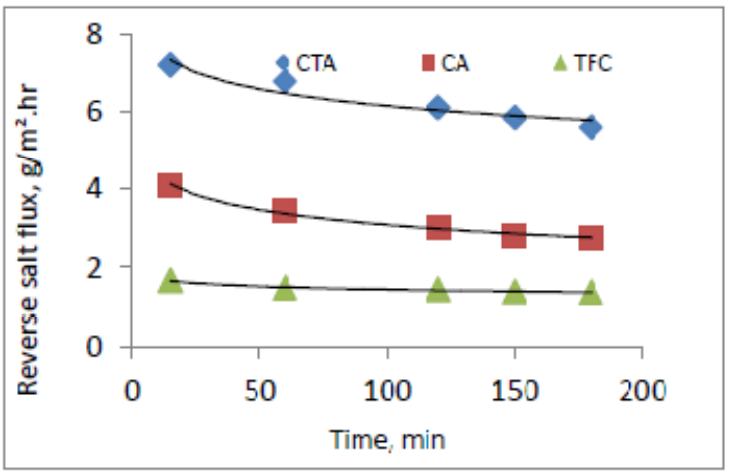

Fig. 9. Change of reverse salt flux with time for different types of membranes $\left(30{ }^{\circ} \mathrm{C}\right.$ temperature, $3 \mathrm{l} / \mathrm{min}$ flow rate, $0.6 \mathrm{M} \mathrm{NaCl})$.

\section{Conclusions}

The permeability flux for osmotically driven CTA membrane is higher than TFC and CA membranes, while the flux increased dramatically for TFC and CA membranes and become much higher than CTA membrane when hydraulic pressure applied. The reverse salt flux for CTA membrane is higher than CA and TFC membranes. In this research, the draw solutions characteristics state that inorganic ionic salt $(\mathrm{NaCl})$ impart little higher flux than organic ionic salt (sodium formate) but much higher than other organic salt (sodium acetate) while the results which obtained for reverse salt flux gave high values for sodium chloride salt when compared with other organic salts which considered drawback for $\mathrm{NaCl}$ salt.

\section{Acknowledgements}

The authors acknowledge the support of the chemical engineering department, college of engineering, university of Baghdad. The authors also acknowledge the water and Environment directorate, ministry of science and technology.

\section{References}

[1]T.S. Chung, X. Li, R.C. Ong, Ge, H.L. Wang, G. Han, Emerging forward osmosis (FO) technologies and challenges ahead for clean water and clean energy applications, Curr. Opinion Chem. Eng. 1 (2013) 246-257.

[2] S. Zhao, L. Zou, C.y. Tang, D. Mulcahy, Recent developments in forward osmosis: opportunities and challenges, J. Membr. Sci. 396 (2012) 1-21.

[3]I.C. Escobar, A summary of challenges still facing desalination and water reuse: I.C. Escobar, A.I. Schafer (Eds.), Sustainable Water for the future water recycling Versus desalination, Elsevier Science, the Netherlands, 2010. Pp. 389-397.

[4] R.W. Holloway. T.Y. Cath, K.E. Dennet, A.E. Childress, Forward osmosis for concentration of anaerobic digester centrate, in: Proceedings of the AWWA Membrane Technology Conference and Exposition, Phoenix, AZ, 2005.

[5]P.P. Bhatt, Osmotic drug delivery systems for poorly soluble drugs, pharma Ventures Ltd., Oxford, UK, 2004.

[6]Ling, M.M., Chung, T.S., Desalination process using super hydrophilic nanoparticles via forward osmosis integrated with ultrafiltration regeneration. Desalination, 2011, 194-202.

[7] Achilli, A., Cath, T.Y., Childress, A.E., Power generation with pressure retarded osmosis: an experimental and theoretical investigation. Journal of membrane science,2009, 343, 4252.

[8]Cath, T.Y., Childress. A.E., Elimelech, M., Forward osmosis : principles applications, and recent developments. Journal of membrane science (2006) 281, 70-87.

[9] Martinetti, C.R., Childress, A.E., Cath, T.Y., High recovery of concentrated RO brines using forward osmosis and membrane distillation. 
Journal of membrane science (2009) 331, 3139.

[10] Achilli, A., Cath, T.Y., Childress, A.E., Selection of inorganic-based draw solutions for forward osmosis applications. Journal of membrane science 2010) 364, 233-241.

[11] K.S., Bowden, A.Achilli, A.E., Childress, Organic ionic salt draw solutions for osmotic membrane bioreactors, Bioresource Technol. 122 (2012) 207-216.

[12] J.R., McCutcheon, R.L., McGinnis, M. Elimelech, The ammonia carbon dioxide farward osmosis desalination process., Water conditioning and purification, (2009) p. 1-4.

[13] G. Qingchum, L. Mingming, C. Tai-Shung, Draw solutions for forward osmosis processes: developments, challenges, and prospects for the future. Journal of membrane science 442 (2013) 225-237.

[14] J.S. Yong, W.A. Phillip, M. Elimelech, Coupled reverse draw solute permeation and water flux in forward osmosis with neutral draw solutes, J. Membr. Sci. 392-393 (2012) 9-17.

[15] V. Yangali-Quintanilla, Z. Li, R. Valladares, Q. Li, G. Amy, Indirect desalination of red sea water with forward osmosis and low pressure reverse osmosis for water reuse, Desalination 280 (2011) 160-166.

[16] Cath, T.Y., Adams, V.D., Childress, A.E., Membrane contactor processes for wastewater reclamation in space. II. Combined direct osmosis, osmotic distillation, and membrane distillation for treatment of metabolic wastewater. Journal of membrane science, (2005) 257, 111-119.

[17] Holloway, R.W., Childress, A.E., Dennet, K.E., Cath, T.Y., Forward osmosis for concentration of anaerobic digester centrate. Water Research, (2007) 41, 4005-4014.

[18] McCtcheon, J.R., Elimelech, M. Influence of concentrative and dilutive internal concentration polarization on flux behavior in forward osmosis. Journal of membrane science, (2006) 284(1-2), 237-247.

[19] G.D. Mehta, S. Loeb, Internal polarization in the porous substructure of a semipermeable membrane under pressure-retarded osmosis, Journal of Membrane Science, 4(1978), 261265.

[20] Tang, C. Y., She, Q., Lay, W. C. L., Wang, R. \& Fane, A.G. Coupled effects of internal concentration polarization and fouling on flux behavior of forward osmosis membranes during humic acid filtration. Journal of membrane science, (2010) 354(1-2), 123133.

[21] Petrotos K.B., Lazarides H.N., Osmotic concentration of liquid foods, J. Food Eng., 49, 201-206.

[22] McCutcheon J.R., McGinnis R.L., Elimelech M., (2005) A novel ammonia-carbon dioxide forward (direct) osmosis desalination process, Desal., (2001) 174, 1-11.

[23] Kravath R.E. and Davis J.A. Desalination of seawater by direct osmosis. Desal., (1975) $16,151-155$.

[24] Achilli A., Cath T.Y., Marchand E.A., Childress A.E., The forward osmosis membrane bioreactor: A low fouling alternative to MBR processes, Desal., (2009) 239, 10-21.

[25] Cornelissen E.R., Harmsen D., de Korte K.F., Ruiken C.J., Qin J., Oo H., Wessels L.P., Membrane fouling and process performance of forward osmosis membranes on activated sludge, J. Membr, Sci., (2008) 319, 158-168.

[26] Nguyen C.N., Shiao S.C., Hau T.N., Huu H.N., Wenshan G.H., Chan W.H., Applicability of a novel osmotic membrane bioreactor using a specific draw solution in wastewater treatment, Science of the total environment 518-519 (2015) 586-594.

[27] Ryan w. H., Andrew S.W., Aline F.S., Jack H., Mark D.S., Keith L., Tzahi Y.C., Long term pilot Scale investigation of novel hybrid ultrafiltration-osmotic membrane bioreactor, Desalination 363 (2015) 64-74.

[28] M.M. Ling, T.S., Chung, Novel dual stage FO system for sustainable protein enrichment using nanoparticles as intermediate draw solute, J. membrane Science 372(1-2) (2011) 201-209.

[29] M.M. Ling, T.S., Chung, Desalination process using super hydrophilic nanoparticles via forward osmosis integrated with ultrafiltration, Desalination 278 (2011) 194202.

[30] Dan Li et al., Stimuli-responsive polymer hydrogels as a new class of draw agent for forward osmosis desalination, Chem. Commun. 47 (2011) 1710-1712. 


\section{دراسة مقارنة لمحاليل السحب العضوية واللاعضوية في عملية التنافذ الامامي}

هدير كاظم محمد*

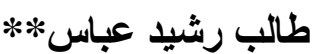

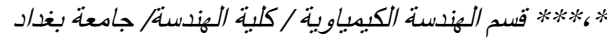

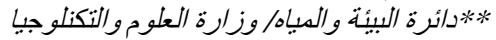

Ahmedalalawy@yahoo.com البريد الالكتروني

Talibrshd@ yahoo.com البريد الالكتروني: البرني:

hadeer_master@yahoo.com البريد الالكتروني:*****
* أحمد فائق العلوي

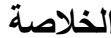

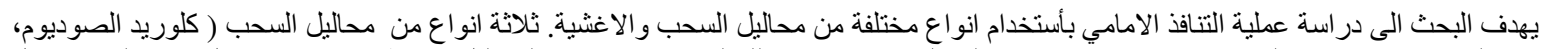

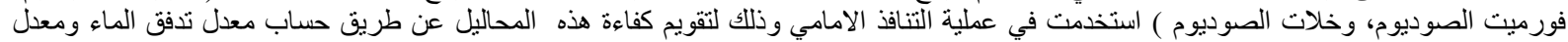

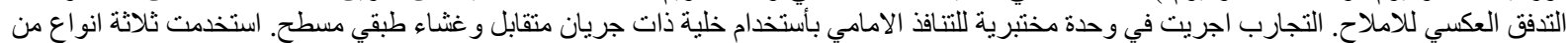

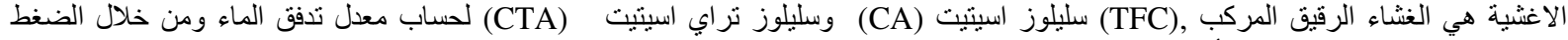

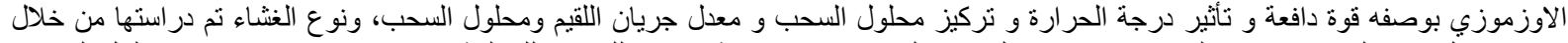

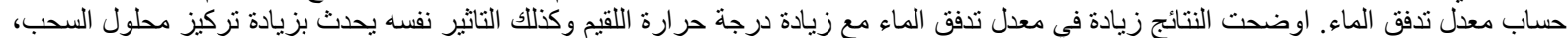

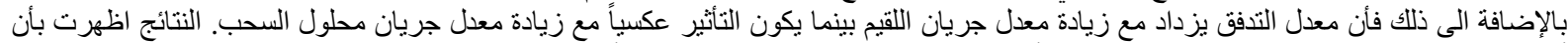

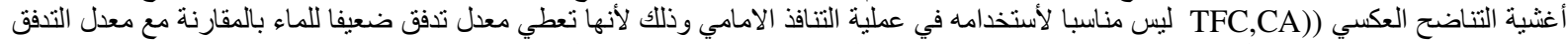

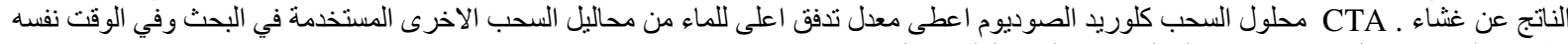
اظهرت الدر اسة معدل تدفق عكسيا اعلى للاملاح بالنسبة لكلوريد الصوديد الصوديوم. 